\title{
Serbian Stories of Translocation: Factors Influencing the Refugee Journey Arising from the Balkan Conflicts of the 1990s
}

\author{
Svetlana M. King, Neil Welch, and Larry Owens \\ Flinders University, Australia
}

\begin{abstract}
$\mathrm{T}$ his qualitative study highlights the experiences of ten Serbian refugees who migrated to South Australia from former Yugoslavia as a result of the Balkan conflicts of the 1990s. Multiple semistructured interviews were employed to examine participants' experiences before, during and after the conflicts. Eight stages of the refugee journey were identified: prewar peaceful co-existence, outbreak of war, fleeing towards refuge in Serbian-held territory, realisation that the pre-war life cannot be regained, dissatisfaction with the family's transition situation, decision and application to emigrate, migration and resettlement in Australia, and adaptation to life in Australia. A number of factors were found to influence each stage of the refugee journey (e.g., social, practical and health challenges, age, and negative Serbian stereotypes). From these findings, three adaptation patterns - active integration, passive integration, and segregation - were identified as specific to the participants in the current study.
\end{abstract}

Keywords: refugees, ethnic conflict, civil war, trauma, adaptation, integration

The only people who understand freedom are those who have lost their freedom.

Over the past decade, the world has seen an increase in the number of refugees and displaced persons. In 2007, the United Nations High Commissioner for Refugees [UNHCR] reported a worldwide refugee population of 32.9 million (UNHCR, 2007). Australia is a significant recipient country for refugee populations, receiving over 700,000 refugees and those in need of humanitarian aid since World War II (Department of Immigration and Citizenship, 2006). The majority of refugees entering Australia since 1991 have come from the Balkans, the Middle East, Afghanistan and, more recently, Africa (Department of Immigration and Multicultural and Indigenous Affairs, 2005).

The refugee journey is characteristically traumatic, and typically involves multiple losses of material and social resources as a consequence of sudden upheaval (Centre for Multicultural Youth Issues, 2006; Favaro, Maiorani, Colombo, \& Santonastaso, 1999; Hobfoll,
1989; Kinzie, 2007). Consequently, there are multiple losses, consequences and aftermaths that can influence the lives of refugees.

The Federated Republic of Yugoslavia was located in Eastern Europe. (Subsequent reference to the Federated Republic of Yugoslavia will be referred to as 'former Yugoslavia.) Prior to its fragmentation, the region consisted of Slovenia, Macedonia, Croatia, Bosnia and Hercegovina, Serbia and Montenegro, and Vojvodina and Kosovo, the two provinces of Serbia.

The 1980s signalled the rise of nationalism following a 40-year period of Communism. In 1991, the nationalist rhetoric played out in the form of civil war as the republics seceded from the federation. At that time, Serbs, like other ethnic groups, resided throughout former Yugoslavia - not solely in today's republic of Serbia. The death and destruction from these wars, lasting throughout the $1990 \mathrm{~s}$, is considerable with 250,000 dead or unaccounted for, and more than 2.5 
million former Yugoslavs made refugees (Silber \& Little, 1997 cited in Riedlmayer, 2007).

Extensive research has been conducted into groups that were affected by the Balkan conflicts of the 1990s both in former Yugoslavia and in countries that provided a place of refuge for Balkan refugees such as Italy (e.g., Favaro et al., 1999), the United States of America (e.g., Weine et al., 1998), and Australia (e.g., ČolićPeisker, 2003). This research has largely focused on Bosnian Muslim, Croatian, and Albanian Kosovar groups. What is notably absent from this research are the reported experiences of Serbian refugees.

This article reports the findings of a study that explored Serbian experiences of trauma and transformation as a result of the Balkan conflicts of the 1990s. We provide a brief description of the three main research questions, and explain the use of multiple semistructured interviewing as the chosen method of data collection. The criteria for participant selection are described before details of the data analysis procedures are discussed. We then present the story of Sanja and Slavko, based on two participants in the study, before exploring the eight stages of the refugee journey and the factors that influence each of these stages. In our analysis of the interview data, three adaptation patterns (i.e., active integration, passive integration and segregation) emerged and are described in our discussion of the results. The article concludes with a discussion of the strengths and limitations of the research and a discussion of the implications of this research.

Amidst the extensive and diverse literature that examines the refugee experience, there are few studies that have adopted a holistic perspective in exploring refugee experiences and circumstances prior to, during and following, migration. This position is reflected by a number of authors (e.g., Khawaja, White, Schweitzer, \& Greenslade, 2008; Porter, 2007) who have suggested that a complete understanding of refugee adaptation requires a comprehensive examination of contributing biological, psychological and social factors. There is also a lack of research literature that examines Serbian experiences of translocation as a result of the dissolution of former Yugoslavia during the 1990s. Reasons for this, like the war itself, are complex. The current study was informed by Elder and Johnson's (2003) life course principles to examine Serbian experiences of translocation as a consequence of the Balkan conflicts of the 1990s.

The processes of personal and social transformation at both the individual and family levels formed the focal points of this research. In order to develop an understanding of these processes, the three research questions were: (1) What was life like for study participants prior to the outbreak of war in the area in which they were living? (2) What experiences led to the study participants' decision to leave their homeland and move to Australia and, more specifically, South Australia? (3)
What experiences have shaped the personal and social adjustment and transformation of study participants since arriving in Australia?

\section{Method}

This research used a qualitative paradigm, and drew upon case study methodology (Stake, 2003, 2005; Yin, 2003). Data were collected using multiple semistructured interviews with participants. Interviewing commenced in December 2008 after ethics approval was granted by the Social and Behavioural Research Ethics Committee at Flinders University.

\section{Participants}

Ten participants were recruited from the metropolitan Serbian community in Adelaide. The first author is of Serbian descent and is involved in the Serbian community, providing opportunities to access participants through snowball sampling. Participants were recruited on the basis of the following criteria: (i) identify as Serbian; (ii) reside in the metropolitan area of Adelaide at the time of the study; (iii) were either born in, or spent the majority of their lives living in former Yugoslavia; (iv) were living in former Yugoslavia at the time of the Balkan conflicts of the 1990s and (v) subsequently migrated as refugees to South Australia. The final sample consisted of five men and five women ranging in age from 29 to 75 at the time of the interviews. Participants lived in different parts of former Yugoslavia prior to, and during, the conflict. Table 1 provides a summary of the demographics of each participant. Please note: the names of participants in this article refer to pseudonyms in order to protect the true identities of the participants.

\section{Interview Guide}

An interview guide was prepared by the authors following five pilot interviews. Interview sessions followed a semistructured format and were focused upon the three phases reflected in the main questions, namely: prior to the conflict, during the war, and following migration. The three main research questions were posed to participants, inviting them to share their experiences during each of these phases. Following their responses to these questions, if further detail was required, more direct questions (e.g., 'Whom did you live with at the time?') were posed. These direct questions were developed on the basis that they would assist in unpacking the three main research questions. Where the information provided was unclear, prompts such as, 'Could you elaborate on that?' were given.

Given that the Balkan conflicts of the 1990s occurred more than ten years ago, participants required time to recall certain elements of their experiences. The use of multiple interviews, therefore, provided opportunities for such reflection. Conducting multiple interviews was 
Table 1

Participant Demographics

\begin{tabular}{|c|c|c|c|c|c|c|}
\hline Pseudonym $^{\mathrm{a}}$ & Gender & Prewar Residence & Prewar Occupation & Age at the time of the War & Migration Age & Years in Australia to 2009 \\
\hline Darko & Male & Croatia & Teacher & 57 & 61 & 14 \\
\hline Milica & Female & Croatia & Teacher & 47 & 51 & 14 \\
\hline Mia & Female & Croatia & Administration clerk & 18 & 22 & 11 \\
\hline Slavko & Male & Croatia & Truck driver & 23 & 32 & 9 \\
\hline Sanja & Female & Croatia & Student & 17 & 26 & 9 \\
\hline Dragan & Male & Croatia & Student & 11 & 15 & 14 \\
\hline Beretka & Male & $\mathrm{BiH}^{\mathrm{b}}$ & Statistician & 33 & 42 & 9 \\
\hline Branislav & Male & $\mathrm{BiH}$ & Unemployed & 19 & 24 & 12 \\
\hline Dejana & Female & $\mathrm{BiH}$ & Seamstress & 28 & 33 & 13 \\
\hline Ana & Female & $\mathrm{BiH}$ & Home duties & 21 & 25 & 14 \\
\hline
\end{tabular}

Note: a used throughout

${ }^{\mathrm{b}} \mathrm{BiH}=$ Bosnia and Hercegovina

also a practical consideration, as it allowed time to cover all three phases of participants' lives in depth. Most participants only required two interviews, with the exception of three participants who were interviewed on three occasions. Subsequent interviews created opportunities for the first author to seek clarification in terms of the data that were collected during previous interviews, and the interpretation of the data. As a form of triangulation, multiple interviews were used to clarify, validate and check the credibility, of the data (Stake, 2003).

\section{Procedure}

Interviews with participants were conducted at a mutually agreed location (i.e., at participants' homes, or the first author's home). In several instances, participants were interviewed with their respective partners. While each participant told their own story, their individual narrative merged with that of their partner. The interaction between participants was seen to act as a trigger for the other person's narrative, thereby further enhancing and validating the data. Despite the merging of these narratives, these participants displayed very different trajectories and adaptation patterns to those of their partners.

As some participants were not fluent in the English language, a bilingual research assistant was present during interviews and was able to interpret where necessary. To ensure interpretations of participants' responses were correct, a clarification process was used with participants. This involved presenting participants with verbal summaries which were, where necessary, interpreted from English into Serbian. This enabled participants to clarify and, if necessary, correct the interpretations that had been made.

\section{Data Analysis}

Data analysis occurred in terms of exploring and analysing the participants' reported experiences. Analysis involved an exploration of the commonalities and differ- ences between participants in terms of their individual narratives, decision-making and coping strategies and the factors that influenced them, challenges (e.g., fleeing their homes, becoming refugees and migrating), and risk and protective factors. Emerging themes were compared with those typically found in the refugee literature. Data analysis assisted in shaping subsequent interviews as it provided opportunities to clarify, and further explore, the issues that emerged during previous interviews. This continuity of analysis was seen to assist in capturing the complexity of participants' narratives. From the data analysis, eight stages of the refugee journey were developed as specific to the Serbian participants in this study. In further analysing the interview data, three adaptation patterns (active integration, passive integration and segregation) emerged.

\section{Results and Discussion}

In an effort to situate the reader within a context, we now present the story of Sanja and Slavko. This story is based on the narratives of two participants from the study, and was chosen because it demonstrates some of the key issues and commonalities that emerged in the interview data. The names and other identifying details have been changed to protect the true identities of the participants. (The stories of other participants can be found in King, Owens, and Welch, 2009). The stages of the refugee journey are then described, including a discussion of the factors that influence each of these stages. Finally, the three identified patterns of adaptation are described.

\section{Sanja and Slavko}

Sanja was barely 17 years old when the war began in Croatia. It was early September 1991, and the beginning of a new school year. Sanja was sitting with her Croatian girlfriend, preparing to leave for school when she heard a thump. Assuming it was the meter reader coming to collect his payment, she ventured outside to find the 
source of the noise. But there was no meter reader. Sanja's parents were running towards her. The war had begun.

Sanja reported that soon after the outbreak of war, a number of buses assisted in evacuating the Croats from her home town. The Serbs 'didn't know [what was] happening and then, in the morning, no Croats [were] left in that part ... just their ... army stayed', as the army barracks were located in the city. Most of the Croatian civilians travelled to nearby villages, taking livestock and pets with them.

Sanja stated that 'overnight, people just completely changed'. Friends and neighbours became enemies. The Yugoslav flag was replaced with the Croatian flag. This display of patriotism resulted in the evacuation of many Serbs from the area, particularly those in positions of influence and power (e.g., doctors, government officials and lawyers). 'Every night, they [the Croats] would ... go and destroy one of [the Serbian] houses'.

During 1991, Sanja, along with the other Serbs who remained in the region, were told to move into the basements of their houses. A special army contingent was coming. Being young, Sanja enquired about this army and was told, 'They are cut-throats from Zagreb who are tonight coming to massacre you'. She only wished she had remained silent.

And then the bombing began.

The attacks became so frequent that people were no longer safe above ground. People sought shelter in cement bunkers beneath their houses.

One day, as the firing began, all the families were moving towards the cement bunkers. Sanja ran into the yard. Her neighbour ran the opposite way. He said, 'Come on! Hurry up, hurry up!' Sanja insisted that she would enter through the backyard. He ran ahead of her and 'that's when a grenade fell', decapitating him. The man fell to the ground, his brain oozing from what remained of his skull. Sanja was only half a metre behind him.

In shock, Sanja proceeded towards the cement bunker to inform the others about the tragedy she had witnessed. They emerged from the bunker to examine the man's remains, and 'took his body and wrapped him up' There was no one to bury the man. His remains, left in the European summer heat, were disturbed by cats that 'climbed all over his body. And the flies came'.

Amidst the hardship and terror of war, Sanja met Slavko in 1991. Before long, they began living together.

One night, as the Croats were raiding Serbian homes, a woman who was walking in the street dared to ask the Croatian soldiers what they were doing. Sanja reported: 'They took her and tied her to a fence, poured petrol over her and set her on fire'. And those in the area 'just watched'. 'Can you imagine when someone's burning alive, the screams of anguish and pain?'

For nearly three years, Sanja and Slavko's region was without electricity, without water, and without food.
People were left with nothing. Slavko reported, however, that they soon became accustomed to this way of life.

Throughout the 5-year conflict, Slavko worked as a soldier, guarding the Serbian territory in Croatia. He would work on this border and would return to Sanja every seven days to shower and sleep.

One August day in 1995, Slavko and Sanja were woken at 5 a.m. to the sound of gunfire. Their town had come under attack. Sanja stated, 'There was gunfire everywhere ... it was non-stop ... like fireworks'. Slavko travelled to the army base, a transformed house, to assist with the Serbian war effort. Sanja wondered if - and when - she would ever see Slavko again.

That same day, at 9 p.m., Sanja fled the region, joining a cavalcade (overseen by Serbian police) of between 150,000 and 200,000 people, travelling towards Serbia. As she walked, Sanja passed many recent burial sites alongside the road - the result of recent attacks made on the convoy of displaced people, and those who were simply unable to complete the journey.

Six days after Sanja left her Croatian home, she was reunited with Slavko whose army unit had disbanded. The couple then completed the journey to Serbia together. It took twelve days.

After arriving in Serbia, Sanja, who was seven months pregnant at the time, began experiencing false labour pains. Slavko took her to the maternity hospital in Belgrade where she was informed that she would give birth to a stillborn baby. Sanja 'refused to stay in hospital'. Fortunately, the labour pains ceased.

The couple were housed at a Serbian refugee camp where they slept on the floor with hundreds of others. They only remained there a short time before moving to more permanent refugee accommodation.

In October 1995, Sanja gave birth to a baby boy. She had nothing for her child, and relied on the Red Cross for assistance. In addition, the conditions in the refugee camp were very poor. The food consisted solely of vegetables. Sanja stated that 'even pigs eat better than that'. Furthermore, there was no work available for refugees, and when there was work, people received minimal pay. The couple then made the decision to leave former Yugoslavia. There was nothing left for them there.

They applied to migrate to Germany. They were rejected. They applied to migrate to Canada. They were again rejected. They lodged paperwork to migrate to the United States of America and were rejected. Finally, they applied to enter Australia. After five years of living in a Serbian refugee camp, the couple's application was accepted, and they arrived in Adelaide in September 2000 with their 4-year-old son.

Initially, Sanja found the Australian lifestyle 'horrible, terrifying'. English confused her. She could not believe that she had to lock the doors to her house. The driving was on the wrong side of the road, and she had to press the button to get a walk light to allow her to cross the road. 
Since 2000, Slavko and Sanja have established a new life for their family. Sanja speaks fluent English. The family currently reside in their own home. Their teenage son attends a private school. And, first and foremost, they are proud to identify themselves as Serbs.

In summarising her experiences, Sanja stated:

It will always remain one wound, but it will slowly go. It will go; it won't be as it was in the beginning. It will grow dimmer, dimmer ... and dimmer into the past, but we will never forget.

\section{The Refugee Journey}

Analysis of the interview data from all ten participants revealed factors that influenced their experiences as refugees and as migrants. We now explore these factors in relation to the identified stages of the refugee journey.

\section{Pre-War Peaceful Co-Existence}

During the Communist era in Yugoslavia, ethnic affiliation was discouraged. At this time, all participants claimed to have led pleasant lives, and reported good relationships with their interethnic neighbours. For example, the majority of Sanja and Slavko's friends were Croatian. Slavko stated that ethnic and religious differences were 'never looked at. [We] never asked ... [and] never questioned'. Similarly, Dejana stated: 'there were no problems with ethnicity'. Participants described these neighbourhood relationships as reciprocal, providing practical and emotional support and friendship. Ana's husband, living in Serbia prior to the war, stated that his neighbours 'were like family'. Beretka, a village dweller, reported: 'For a peasant, they find it difficult without their fellow villagers ... We're tied to our people, we're tied to our community'.

\section{Outbreak of War}

During the 1980s, extremists promoted ethnic nationalism as a solution to the economic and political decline that resulted after the fall of Communism (Centre for Balkan Development, 1996). Prior to the official outbreak of civil war, participants reported that they became acutely aware of ethnic tension as it began to disrupt the social fabric of their lives. Dejana stated:

It was very common for people to help each other. Even to the extent that when a church was being built, the Muslims would contribute, and if a mosque was being built, the Serbs would contribute ... and then, everything fell down like a house of cards.

The outbreak of war resulted in the shattering of participants' relationships. Dejana reported that 'neighbours became strangers'. Participants expressed disbelief at the developing turmoil. As Sanja stated: 'Overnight, people just completely changed'. Dragan described the situation at school. Where he and his friends had once referred to themselves as Yugoslavs, they 'began to divide [themselves]' according to their separate ethnic identities. Branislav alluded to the betrayal he felt by his neigh- bours: 'You live with them [for] ten years ... now how can you trust them? They don't trust you ...'

Family relationships were also threatened as male family members participated in the war effort (as was the case with Sanja and Slavko), or were incarcerated. Beretka stated:

At the beginning of the war, I was prepared to die ... If I was able to save the ... people [in my village], if I lost my life, I would have been successful on this earth.

The absence of male family members created additional stress for participants and their families. At this time, Sanja feared for her father's safety, and 'whether he would be killed'. All participants expressed a desire to keep their families together during the war. Dejana, whose husband was imprisoned for four years, stated that '[she] remained in Sarajevo to be near [her husband]'.

Amidst shattered networks, participants reported that threats were placed on their physical safety. Dejana experienced bombardments in which she was forced to become a human shield for her baby. She stated: 'The feelings at that time are indescribable'. Sanja's physical safety was also directly threatened as she made her way to an underground bunker 'when a grenade fell', killing her neighbour. Dejana reported an incident in which she was fired upon by a drunken Bosnian Muslim soldier as she held her baby in her arms. During this incident, Dejana's daughter fell asleep in her arms. Dejana stated that she 'just laughed' from the shock and surprise at her daughter's response. Dejana also experienced countless sniper attacks while seeking humanitarian aid food packages: ' $\ldots$ the metal wheelbarrow we had ... containing flour and sugar and oil ... was peppered with bullet holes ... but we escaped ... we were unharmed'.

Such physical threats possessed the potential to jeopardise the mental health and wellbeing of participants and their families. Dejana acknowledged the torture her husband endured during his incarceration has left him 'totally psychologically shaken'. The disbelief at the ethnic polarisation that shattered participants' social networks, coupled with the physical threats to participants' safety created fear and uncertainty about the future. As Branislav stated:

It's not easy ... you don't know what to do ... where to be,
or what's going to happen ... if war is starting ... the time
was changing, everything was happening, you don't know
what to do, where to be, what's going on. Should you leave
your home, [or] go somewhere else? You don't know, [there
are] so many questions, and it's very hard.

\section{Fleeing Towards Refuge in Serbian-held Territory}

Participants' decisions to flee their homes were based on perceived threats, stories of interethnic atrocities, community voices inciting interethnic hatred and retaliation, the abrupt ending of relationships with former interethnic friends and hostile reactions from these people, and a lack of any effective means of verifying rumours. Such conditions contributed to promoting and heightening 
participants' fears for the safety of themselves and their families, socially isolating them as Serbs from their interethnic neighbours, and increasing their distrust of those belonging to non-Serbian ethnic groups.

For Sanja, 'women's gossip in the street' was the major form of communication during the war, given the lack of electricity in their region. It was through gossip that Sanja learnt of the 'rivers of blood' in the old hospital in her town, left after the massacre of Serbian people. Branislav, however, had access to television news reports, and watched programs controlled by Croats, Bosnian Muslims, and Serbs because he 'wanted to determine the truth ... [and] just wanted to understand what's happening'. Similarly, Milica stated: 'The truth was sometimes inconceivable and unfathomable ... We couldn't get to the real truth .... The decisions participants made were influenced by concerns for the physical and mental health and wellbeing of their families. In explaining why the family fled, Milica stated that if they had stayed, 'there was no chance. You would just walk into death ... and what would you do, take your child ... so that it could be killed? You can't'.

In travelling towards Serbian-held territory, participants faced new practical challenges such as finding food and arranging accommodation. For example, Slavko reported: 'When we travelled in [the] cavalcade, we would go past houses and cafes and hotels and people offered us assistance without us having to pay for anything. While Sanja and Slavko reported that there was no time to shower as the convoy moved quite quickly, they did accept food that sustained them throughout the journey.

The decision to flee to Serbian-held territory was formed and reinforced by negative images of Serbs as the sole transgressors of the conflicts, and fear of retaliation by non-Serbian ethnic groups. Such images were portrayed in international media reports about the conflicts (Clark, 2008; Sekulic, Massey, \& Hodson, 2006). Seeking refuge in Serbian territory, therefore, would have resulted in a degree of acceptance in light of the public retribution experienced by the Serbian population as a whole. Darko, for example, experienced no tension with others who were living in Serbia, which included Croatians: 'No one knew what was going on ... No distinctions were made [between the Serbs and Croats]' in Serbia.

Once in areas of refuge, participants identified new challenges. For Milica, these challenges included coming to terms with the notion that she and her family 'were refugees in [their] own country'. Some participants reported mental health difficulties in light of the trauma they experienced during the conflicts. Beretka acknowledged that he began to suffer depression which required treatment, and had contemplated committing suicide. He recalled this as 'the worst period of [his] life'. In addition to these challenges, participants reported practical challenges associated with being refugees. After living with relatives for a period of time, Darko stated: 'We saw that we weren't able to all be there together, so we needed to find somewhere else to live'. Milica reported that her family moved 'about fifteen times' after fleeing their Croatian home. Milica also stated that she received aid from the Red Cross: 'If we didn't have help, we wouldn't have had anything. In addition to the financial strain of paying the family's rent, Milica acknowledged that she became distressed after being unable to financially provide her child with basic stationery for school. She stated: 'That was the first time I experienced incredible pain and hardship'. Sanja and Slavko reported a lack of employment opportunities for refugees, which created a financial strain on the family:

'Every time ... [Slavko applied] for [a] job, they said, "There's no job for refugees". And then, they gave you some work, those people [who] live there, around [the] house or something, so you work for food and maybe, for [a] full day, they gave you ten dollars.

In addition, Sanja indicated that the refugee camp lacked nutritious food: 'We never had meat, just vegetable[s] ... and it didn't taste right'.

After becoming refugees, participants established new social networks in order to restore sources of emotional and practical support that they had lost. Milica stated that, through employment, she was able to establish new friendships. Branislav stressed that amidst the development of new relationships, he became wary of others. He stated: 'In war ... you can see real people's faces ... someone that you trust a lot and that you thought was your friend, it was shown [to be] opposite, alluding to the fact that people's appearances became deceiving. Dejana and Beretka echoed this distrust, acknowledging that their war experiences had caused them to lose trust and faith in people.

\section{Realisation that the Pre-war Life Cannot be Regained}

All participants expressed the belief that the refuge they sought at this stage would be transitory and, after a short period of civil conflict, they would be able to return to their homes and resume their lives. Milica reported: 'We still had hope. We still lived in hope ... that it would all stop. The way it started, we hoped it would finish. She also stated: 'We had every ... intention that when the firing and bombardments ceased, that we would just return and resume our lives'. Dragan stated that he 'didn't visualise at that time that [he would] never [go] back to ... Croatia, so [he] wasn't sad when [he] left'.

After recognising that the conflicts would not be short-lived, participants realised that they would be unable to return to their prewar lives. Participants reported that their prewar social networks remained shattered, and that they were no longer accepted by their neighbours and friends. For example, Milica stated that her best friend simply 'turned her head and went the other way'. In addition to the lost social networks, participants also identified material losses that prevented them 
from returning to their prewar lives. Dejana's house was razed to the ground: 'I witnessed my house, where I was born, burn'. Slavko indicated that his mother had sold the family home and moved to a different region of former Yugoslavia. Darko stated that his family's home had been confiscated, and was being occupied by Bosnian Muslims: 'When we didn't return, the Croatian authorities ordered that all the Croats from Bosnia, they were to be resettled in our [Serbian] houses ... They got our house'. Milica went further to report that 'there were 18 people living in [their] house'.

\section{Dissatisfaction with the Family's Transition Situation}

Participants reported that after becoming refugees, their prewar education and employment opportunities were no longer available to them. For example, Milica stated that she and her husband 'didn't go back [to Croatia], so they were fired' from their respective positions. She reported that their Serbian identities 'sped up [the process] of [their] removal [from Croatia]'. Dragan's education in Croatia abruptly ended when he became a refugee and had to complete his education in Serbia. Fortunately, because of the timing of his family's departure, Dragan 'didn't miss one day of school'.

Age and life stage were seen as critical factors in this part of the refugee journey. Older participants (e.g., Darko, Milica, and Beretka) had more established financial, material, educational and employment assets than younger participants (e.g., Dragan, Sanja, and Mia). Because of this, older participants were grieving the loss of more extensive resources than younger participants.

\section{Decision and Application to Emigrate}

After living in transitional arrangements for a period of time, participants reported a desire for permanency and stability in terms of employment, education and economic opportunities. Participants had lost much of their independence and control over their lives, and had a much lower standard of living than in the prewar period. Diminished education, employment and lifestyle opportunities resulted in participants experiencing emotional and financial hardship. Slavko stated: 'The main reason [for leaving former Yugoslavia] was to give our children a better life, to be their own person, to complete something. We thought, at that time, over there, you couldn't'. Sanja further added: 'And because of us. There was nothing for us. You can't live in one room, all of us, or working for ten bucks'. Similarly, Darko stated that he and his family 'were looking for a better life'. For Dejana, the trauma experienced during the war prompted her desire for a better life outside of former Yugoslavia, a place which created many bad memories for her. She stated: 'It's like returning to a snake pit where you were once bitten ... and you return again and you are told the snakes won't bite you'. In summary, participants were in search of safety and security for their families.
For Slavko and Sanja, the application process involved a number of setbacks. Despite this, the couple reported a determination to provide a better life for their child and for themselves. After lodging their application to migrate to Australia, Sanja reported: 'We said, that's it ... and after [a] few weeks, they said yes. I couldn't believe it'. Similarly, Beretka stated that he experienced difficulties in applying to migrate to Australia. He applied on two separate occasions before being accepted. He stated:

It was third time lucky for me to come to Australia ... They let me and my wife come to Australia and they saw that we were good students, good pupils, and that we would have children ... but they wouldn't allow my parents to come.

For other participants, applying to migrate to Australia was a more straightforward process.

Participants reported mixed feelings about migrating to Australia. This was found to be related to participants' ages. For example, Darko reported: '[Our children] were overjoyed. They were happy'. Milica stated, however, that she and Darko 'were afraid ... [Darko] was a sceptic'. Younger participants (i.e., Dragan, Mia, and Branislav) were excited at the prospect of beginning a new life and taking up new education and employment opportunities. Mia reported: 'Australia sounds to me ... like [a] mystic country ... I was just ... excited about everything ... It was great ... I utilised all [these] opportunit[ies] to go and finish my study'. Some participants reported feelings of grief at losing yet another resource - their country. For example, Beretka stated that '[he] didn't know what nostalgia was until [he] migrated to Australia'. This feeling was echoed by Mia, who indicated that she was continuing to experience grief at the loss of her homeland: 'I'm so, so homesick and it's just becoming ... [worse] ... I don't have my best friend here ... [and I'm] homesick for [the] country'.

\section{Migration and Resettlement in Australia}

All participants, regardless of age, were faced with learning to adapt to a new culture and lifestyle, reinforcing the concept that learning is a lifelong process (Adams, 2007; Vorhaus, 2002). Education and employment opportunities were found to be critically influenced by age and life stage. In terms of the learning associated with adaptation, individuals have a tendency to avoid and fear situations that are perceived to exceed their strategies of coping (Bandura, 1977, 1997), which is influenced by age. The coping strategies an individual uses influence the experiences they have (Rutter, 2007).

Learning to be fluent in the dominant language of the host country is an important determinant of how immigrants (including refugees) will adapt upon resettlement (Burgoyne \& Hull, 2007). The three oldest participants (i.e., Darko, Milica and Beretka), for example, reported difficulties in learning English, and currently possess only basic skills. In contrast, the three 
youngest participants (i.e., Dragan, Mia, and Branislav) reported fewer difficulties and, consequently, are more fluent English speakers. Čolić-Peisker (2002) suggested that children are able to acquire language skills naturally through their schooling; adults, however, must allocate special time and effort to language acquisition. Poor mental health was also found to be a barrier to learning English. Beretka, for example, reported that his mental illness, combined with a lack of 'flair' for language, had made it difficult for him to learn the dominant language. Individuals experiencing mental health challenges may be reluctant to put themselves into potentially stressful situations (e.g., learning English) that could exacerbate these difficulties, particularly if supportive others are absent. Family commitments (e.g., caring for small children), particularly those of the younger female participants (i.e., Ana and Sanja), were also seen as a factor that limited education and employment opportunities.

Six participants (i.e., Darko, Milica, Slavko, Beretka, Branislav and Ana) had difficulties with spoken English. They could be said to be living in an 'ethnic bubble' (Čolić-Peisker, 2002, p. 156). Given the provision of facilities such as local Serbian businesses, and Serbianspeaking social workers, lawyers, doctors and priests, these participants were essentially able to live in 'ethnic isolation', which is consistent with the findings of ČolićPeisker (2002, p. 156). This isolation from the wider Australian community is likely to have influenced participants' adaptation following migration.

Amidst these obstacles, participants were faced with the challenge of coping with negative Serbian images in the media. All participants felt very strongly that the Serbs were grossly misrepresented in the media throughout the Balkan conflicts. Dragan stated:

It was a shock to me ... and still [is] today that [the] media is not covering both stories which is the first part of any media reporting ... but I see that with BBC ... and good television [they are reporting both sides] ... [With other media, however,] ... there is always one side which is good and the other side is bad ... why they are doing that continuously, I don't know ... how can you present a whole nation as being negative?

Ana's husband, Zoran stated:

The way that things work these days, you have to pay to get the public opinion on your side. You have to pay the money, regardless if you're right or wrong, you have to pay the money ...

Dejana indicated that there have been no public images of Serbs who suffered during the 1990s. She stated: 'That's what killed us the most, when you see the injustice ... I never believed there were people like that who could tell such lies'.

\section{Adaptation to Life in Australia}

Two years after migrating to Australia as refugees, participants became Australian citizens, thereby making their migration more permanent. Today, participants are still learning to adapt to life in Australia. Many were still experiencing unresolved grief and loss issues, and some have continued to experience mental health difficulties. Dejana reported that her husband had been psychologically scarred as a result of his incarceration and torture, requiring a battery of medications 'just to function' normally each day. She indicated that her husband's continued nightmares result in broken sleep, where he awakens, shaking and screaming. In addition, his hearing is impaired from the constant beatings he received in prison. While she reported that these posttraumatic effects take their toll on the family, Dejana's resilience had a positive influence on all members of the family, particularly her children.

Participants indicated that, since migration, they have been engaged in constant re-evaluations of their dual identities as both Serbs and Australians. For example, Beretka stated: 'I feel Serbian, but my passport says I'm Australian'. Dragan reported that when he is living in Australia, he identifies as Serbian. When he visits former Yugoslavia, he identifies as an Australian. He stated: 'I'm living two lives definitely ... at the moment ... I feel that I belong in both places ... at the moment, I don't see [a] problem with that'. Ana's husband reported:

I'm a Serbian born in Australia ... I consider myself more Serbian because I grew up over there, but more and more I become more Australian ... Now, it's getting very, very close to being ... equal.

Participants' identities have been shaped by historical and political circumstances, negative stereotypes and through their relationships with others. While some participants have maintained a connection to their homeland, other participants, because of their traumatic war experiences, asserted that they would never consider returning to their country. For example, Dejana stated: 'I would rather go and beg on the street than go back there'.

Following migration, participants established new social networks within the Adelaide Serbian community. None of the participants, however, indicated having an extensive group of close friends, which may be a consequence of the distrust and suspicion of others instilled in them during the war. Furthermore, participants' needs for friendship and practical and social support may have been met in their immediate families, which were seen as the major source of support and companionship. Beretka stated that 'family is everything' to him. Similarly, Dejana emphasised that 'family is the most important thing [she has]' and her main priority is to ensure that her children 'make something of themselves'. Despite the challenge of displacement, and structural transformation, family has remained a significant and crucial element of participants' lives. Dragan reported:

We are pretty solid as a family ... when you have a solid family, [it doesn't] matter where you live ... You can go wherever and still the life within family is the same. And if it's healthy, the outside world can't damage it ... . 


\section{Patterns of Adaptation}

Analysis of the interview data resulted in the identification of three adaptation patterns that are specific to the participants in the study: (i) active integration (ii) passive integration and (iii) segregation. These patterns emerged from the analysis of participants' stories. In considering these adaptation trajectories, it is important to acknowledge that the factors which characterise each adaptation pattern operate in complex ways. For example, the challenges of older age can exacerbate mental health issues which, in turn, impede an individual's ability to cope with new challenges. These factors, therefore, do not always operate in isolation; individual factors can affect other factors in complex and interwoven ways.

It is interesting to note that members of the same family can adopt different patterns of adaptation. This suggests that these patterns interact in a complementary manner, where active integrators assist the passive integrators and segregators in their families.

\section{Active Integration}

Participants who followed this adaptation pattern embraced migration-related changes, actively integrated into the Australian and Serbian communities and displayed optimism about the future. These participants actively engaged in education and employment opportunities made available to them, enabling them to become involved in skilled employment. For example, Mia completed studies in tourism before becoming employed at a travel agency. Family members who adopted a segregation adaptation pattern were typically heavily dependent upon the active integrators in their families. Those seen to follow this adaptation pattern were typically younger, male participants experiencing good mental health and wellbeing (e.g., Branislav and Dragan). These participants were typically resilient and possessed supportive social networks that were coupled with the implementation of effective coping strategies. It is possible that the educational values of the participants' parents influenced their willingness to undertake new education and employment opportunities, and positively contributed to the participants' overall adaptation.

\section{Passive Integration}

Passive integrators typically did not pursue English language classes, resulting in a language barrier that likely contributed to their social segregation and occupation within an ethnic bubble (e.g., Dejana). Further education was not pursued and was most likely the result of a limited command of the English language. Participants who followed this adaptation pattern reported involvement in unskilled employment where English proficiency was not a requirement. These participants were typically the primary financial providers for their families (e.g., Slavko). Due to the language barrier, however, passive integrators were relatively dependent upon English- speaking family members. Passive integrators, like active integrators, also reported involvement in the Serbian community. Participants who followed this adaptation pattern were older, and experienced mental health issues resulting from traumatic war experiences (e.g., Beretka). Passive integration involved male participants who experienced difficulty coping with multiple resettlement challenges.

\section{Segregation}

Participants whose adaptation followed a segregation pattern typically did not pursue English language classes, resulting in a language barrier that impeded further education opportunities. Segregators did not pursue paid employment opportunities, instead undertaking voluntary work in the Serbian community as demonstrated through their involvement in community-based organisations (e.g., Darko and Milica). Participants following this adaptation pattern were typically characterised by financial dependence on the government, with or without financial dependence on immediate family members. These participants were also reliant on English-speaking family members. Segregators included older participants with mental health issues arising from war-related experiences of trauma. These participants struggled to cope with multiple resettlement challenges. Female primary caregivers, however, also occupied this adaptation pattern (e.g., Sanja and Ana).

\section{Limitations of the Study}

The study involved ten participants, all of whom were associated with the South Australian Serbian community at the time of participation. This small number of participants, however, enabled the complex nature of participants' stories to be explored in depth, resulting in the development of rich, contextualised conclusions.

The traumatic events that occurred during the dissolution of former Yugoslavia occurred nearly twenty years ago. The reliability of the data, therefore, was largely dependent on participants' memories. There is evidence that memories can undergo significant reframing over time (Eakin, 1999; Fivush, 2008) as a result of new information, new life experiences, forgetting and reflection. Such a reframing process is expected to have influenced the memories of participants in this study. The use of multiple interviews with participants, however, provided participants with time to reflect upon and recall their experiences. Re-interviewing participants also enabled the clarification of any concerns, ensuring that the interview records accurately reflected what the participants wanted to say.

The situations and circumstances experienced by participants could be considered a limiting factor of the research. Serbian people who were incarcerated during the Balkan conflicts of the 1990s were not represented in the sample but, rather, emerged in the reported experi- 
ences of participants' significant others. While such participants were sought, those who were invited to participate refused, citing that recalling the events would be far too traumatic. It is possible that in years to come, these people may wish to tell their stories.

The study is limited in that there were no corroborative interviews with other family members, except in instances where two participants (i.e., spouses) were interviewed together. Further study could incorporate multiple informants (e.g., service providers, schools, and other family members) in order to obtain multiple perspectives of the 'same' events.

Participants were reluctant to speak about certain issues regarding their experiences of translocation (e.g., political details about the start of the conflicts, the gruesome details of violent acts and burial of the dead). Similarly, participants appeared to find difficulty in collaborating in the exploration of their narratives beyond a superficial level (e.g., participants did not see the relevance in discussing the processes they used to make decisions and, therefore, did not expand on this). This may be because of a distrust of authority figures (such as the university) regarding personal information - a result of the misinformation participants received from government officials during the war. Participants may have also experienced difficulty in remembering the details of their situations.

For those participants who spoke mainly in Serbian during interviews, interpreting was required. This may have disrupted the flow of participants' testimonies. Conversely, participants who predominantly spoke in English, their second language, may have been less able to express themselves in English than in their native language.

The first author's involvement in the Serbian community was both a strength and a limitation in the current study. The cultural knowledge of the first author enabled interview questions to be assessed for their cultural appropriateness. While the author's community involvement may have influenced what participants chose to disclose, the first author was perceived as sympathetic towards participants as Serbs.

\section{Implications and Applications}

Data analysis revealed that participants did not consider themselves entirely independent agents, but rather saw their lives as being inextricably entwined in the lives of members of their families and members of their wider social networks. Participants made decisions with others in mind, and demonstrated a deep concern for the wellbeing of family members. This interdependence and commitment to family was revealed through the reported decision-making associated with displacement and migration. Similarly, coping strategies were also seen to operate on a social rather than an individual level, and were seen to be crucially shaped and influenced by par- ticipants' families. Participants, therefore, exercised personal agency in shaping their lives, doing so within the constraints and opportunities of social, cultural and historical contexts.

Chronological age and life stage appeared to be a critical determinant in shaping participants' reported experiences. The repercussions and implications of becoming a refugee, and the opportunities available following migration were found to differ substantially between adults and adolescents.

The current study has given voice to ten Serbian refugees who migrated to Australia following the Balkan conflicts of the 1990s. It has provided a context in which to understand their circumstances, experiences, and challenges. In addition, this study has resonated with other research concerning the refugee experience. These findings contribute to our understanding of the needs and the challenges facing refugees. This study has highlighted the importance of the social, cultural, historical and political contexts an individual encounters. In addition, the age and life stage of a person will affect the types of experiences an individual will encounter throughout the stages of the refugee journey. This study emphasised the strong links between individuals and their families - the greatest source of social support. Such factors are critical in capturing the 'totality' (Porter, 2007, p. 428) of the refugee experience.

Due to the predicted increase in the global refugee population as a consequence of global warming and ongoing conflict around the world, further research into the experiences of refugee populations is certainly warranted. It is imperative that we develop an understanding of effective ways to meet the social, emotional, and practical needs of these people, both during — and following - migration.

\section{Author Note}

This article reports the findings of a study conducted by the first author in the School of Education at Flinders University under the supervision of the second and third authors.

\section{References}

Adams, D. (2007). Lifelong learning skills and attributes: The perceptions of Australian secondary school teachers. Issues in Educational Research, 17(2), 149-160.

Bandura, A. (1977). Self-efficacy: Toward a unifying theory of behavioral change. Psychological Review, 84(2), 191-215.

Bandura, A. (1997). Self-efficacy: The exercise of control. New York: Freeman.

Burgoyne, U., \& Hull, O. (2007). Classroom management strategies to address the needs of Sudanese refugee learners. Adelaide, Australia: National Centre for Vocational Education Research. 
Centre for Balkan Development. (1996). History of the war in Bosnia. Retrieved 26 December, 2007, from http://www. friendsofbosnia.org/edu_bos.html

Centre for Multicultural Youth Issues. (2006). Information sheet: Refugee young people and resettlement. Carlton, Australia: Centre for Multicultural Youth Issues.

Clark, J.N. (2008). Collective guilt, collective responsibility and the Serbs. East European Politics and Societies, 22(3), 668-692.

Čolić-Peisker, V. (2002). Croatians in Western Australia: Migration, language and class. Journal of Sociology, 38(2), 149-166.

Čolić-Peisker, V. (2003). Working Paper No. 97: Bosnian refugees in Australia: Identity, community and labour market integration. Murdoch, Western Australia: The UN Refugee Agency Evaluation and Policy Analysis Unit.

Department of Immigration and Citizenship. (2006). Fact Sheet 60: Australia's refugee and humanitarian program. Retrieved December 9, 2008, from http://www.immi.gov. $\mathrm{au} /$ media/fact-sheets/60refugee.htm

Department of Immigration and Multicultural and Indigenous Affairs. (2005). A new life for refugees: Australia's humanitarian program: A resource for schools. Retrieved 22 March, 2009, from http://www.immi.gov.au/media/publications/ pdf/A_New_Life_1.pdf

Eakin, P.J. (1999). How our lives become stories: Making selves. Ithaca, NY: Cornell University Press.

Elder, G., \& Johnson, M. (2003). The life course and aging: Challenges, lessons, and new directions. In R. Settersten (Ed.), Invitation to the life course: Toward new understanding of later life (pp. 49-81). Amityville, New York: Baywood Publishing Company.

Favaro, A., Maiorani, M., Colombo, G., \& Santonastaso, P. (1999). Traumatic experiences, posttraumatic stress disorder, and dissociative symptoms in a group of refugees from former Yugoslavia. Journal of Nervous and Mental Disease, 187(5), 306-308.

Fivush, R. (2008). Remembering and reminiscing: How individual lives are constructed in family narratives. Memory Studies, 1(1), 49-58.

Hobfoll, S.E. (1989). Conservation of resources: A new attempt at conceptualising stress. American Psychologist, 44(3), 513-524.
Khawaja, N.G., White, K.M., Schweitzer, R., \& Greenslade, J. (2008). Difficulties and coping strategies of Sudanese refugees: A qualitative approach. Transcultural Psychiatry, 45(3), 489-512.

King, S.M., Owens, L., \& Welch, N. (2009). From fighting to freedom: Stories from Serbian Balkan war refugees. Adelaide, South Australia: Shannon Research Press.

Kinzie, J.D. (2007). PTSD among traumatized refugees. In L.J. Kirmayer, R. Lemelson \& M. Barad (Eds.), Understanding trauma: Integrating biological, clinical and cultural perspectives (pp. 194-206). New York: Cambridge University Press.

Porter, M. (2007). Global evidence for a biopsychosocial understanding of refugee adaptation. Transcultural Psychiatry, 44(3), 418-439.

Riedlmayer, A.J. (2007). Crimes of war, crimes of peace: Destruction of libraries during and after the Balkan wars of the 1990s. Library Trends, 56(1), 107-132.

Rutter, M. (2007). Resilience, competence, and coping. Child Abuse and Neglect, 31(3), 205-209.

Sekulic, D., Massey, G., \& Hodson, R. (2006). Ethnic intolerance and ethnic conflict in the dissolution of Yugoslavia. Ethnic and Racial Studies, 29(5), 797-827.

Stake, R. (2003). Case studies. In N. Denzin \& Y. Lincoln (Eds.), Strategies of qualitative inquiry (pp. 134-164). Thousand Oaks, CA: Sage.

Stake, R. (2005). Qualitative case studies. In N. Denzin \& Y. Lincoln (Eds.), SAGE handbook of qualitative research. Thousand Oaks, CA: SAGE.

UNHCR. (2007). Global trends: Refugees, asylum-seekers, returnees, internally displaced and stateless persons. Retrieved December 10, 2008, from http://www.unhcr.org/ statistics/STATISTICS/4676a71d4.pdf

Vorhaus, J. (2002). Lifelong learning and the new educational order? Journal of Philosophy of Education, 36(1), 119-129.

Weine, S.M., Vojvoda, D., Becker, D.F., McGlashan, T.H., Hodzic, E., Laub, D., et al. (1998). PTSD symptoms in Bosnian refugees 1 year after resettlement in the United States. American Journal of Psychiatry, 155(4), 562-564.

Yin, R.K. (2003). Case study research: Design and methods (3rd ed.). Thousand Oaks, CA: SAGE. 